\title{
A comparative study of maternal outcome between vacuum extraction and outlet forceps delivery
}

\author{
Shilpi Singh*, Munikrishna M., Sheela S.R.
}

Department of Obstetrics and Gynecology, Sri Devaraj Urs Medical College and University, Tamaka, Karnataka, India

Received: 10 April 2018

Accepted: 02 May 2018

\section{*Correspondence:}

Dr. Shilpi Singh,

E-mail: shilpi_dudu@yahoo.co.in

Copyright: () the author(s), publisher and licensee Medip Academy. This is an open-access article distributed under the terms of the Creative Commons Attribution Non-Commercial License, which permits unrestricted non-commercial use, distribution, and reproduction in any medium, provided the original work is properly cited.

\section{ABSTRACT}

Background: Instrumental delivery is an art that is fading and may disappear in the near future as more and more obstetricians are resorting to caesarean sections. Instrumental vaginal deliveries comprise the use of vacuum assisted devices and /or forceps to assist in delivering a fetus, offering the alternative to accomplish vaginal delivery in properly selected cases thereby reducing maternal morbidity in terms of blood loss and increase hospital stay which is a consequence of cesarean sections. The objective of the present study is to compare the maternal morbidity with vacuum and outlet forceps delivery.

Methods: A prospective comparative study was conducted in women delivering at department of obstetrics and gynaecology, in SDUMC, R L Jalappa Hospital, Kolar from March 2016 - March 2017 for a period of one year. A minimum of 180 patients were taken up for study. 90 women delivered by outlet forceps delivery and 90 women by vacuum delivery. Cases which require instrumental vaginal delivery and fulfilling the inclusion criteria for forceps or vacuum were taken up for the study, after taking informed consent. Maternal outcomes including episiotomy wound and extension, perineal tear, post-partum hemorrhage, hospital stay was analyzed and compared.

Results: Mostly forceps and vacuum were applied for age group of 26-30 years and primigravida, which showed a statistical significance. Extension of episiotomy was more with forceps that is $21.1 \%$ and with vacuum being $4.4 \%$. This difference was statistically significant. Postpartum hemorrhage was also more common in forceps group that is $13.3 \%$ compared to vacuum $11.1 \%$ but the difference was not statistically significant. The need for blood transfusion was seen more in cases of forceps that is $11.1 \%$ cases whereas in vacuum i.e. $6.7 \%$ cases but was not statistically significant.

Conclusions: With the expertise and appropriate decision on the indication and meticulous handling of the instrument whether outlet forceps or vacuum, especially in a tertiary care centre, the maternal outcome is equally good with both the instruments.

Keywords: Instrumental vaginal delivery, Outlet forceps, Vacuum

\section{INTRODUCTION}

Instrumental delivery is an art that is fading and may disappear in the near future as more and more obstetricians are resorting to caesarean sections. In the advent of modern medicine along with the advancement of surgery as an option and simultaneous breakthroughs achieved in the field of anesthesia the science and art of operative deliveries will become a thing of the past and will be reminisced as an anecdote in the history of medicine. The ultimate aim of antenatal care is achieving optimal health of the mother and the neonate at the end and hence the need to reassert the importance of operative vaginal deliveries.

Instrumental vaginal deliveries comprise the use of vacuum assisted devices and /or forceps to assist in delivering a fetus, offering the alternative to accomplish 
vaginal delivery in properly selected cases thereby reducing maternal morbidity in terms of blood loss and increase hospital stay which is a consequence of cesarean sections. Historically various types of forceps such as high forceps, rotational forceps and mid cavity forceps been used but are obsolete in the era of modern obstetrics. The only accepted form of forceps used today is the outlet forceps. The rationale behind vacuum assisted delivery is the application of the suction device or cup to a pump in order to create adequate negative pressure allowing traction to be exerted on the fetal head thereby facilitating the delivery via the birth canal.

Among the developed countries the rates of instrumental vaginal delivery range between $5-20 \%$ of all births. In the U.K incidence is between $10-12 \%$, in United States of America is $3.6 \%$ and in India it is documented as $3.1 \%$ .$_{1,2,3}$ Hence the need for this study in today's modern era of elective and repeat cesarean sections where the morbidities to delivering women have increased many fold, simultaneously leading to increase in the incidence of rate of cesarean sections, along with the fact that the expertise and the know-how of instrumental deliveries is diminishing and fading among the younger obstetricians.

\section{METHODS}

A prospective comparative study was conducted in women delivering at Department of Obstetrics and Gynaecology, RL Jalappa Hospital, attached to Sri Devaraj Urs Medical Academy, Kolar from March 2016 March 2017 for a period of one year.

A minimum of 180 patients was taken up for study. 90 women delivered by outlet forceps and 90 women by vacuum. Cases which require instrumental vaginal delivery and fulfilling the inclusion criteria for forceps or vacuum were taken up for the study, after taking informed consent.

Forceps or Vacuum application will be done using American College of Obstetrics and Gynaecology (ACOG guidelines 2010). Indication for forceps or vacuum application was noted in each case.

Table 1: Inclusion criteria.

\begin{tabular}{|ll|}
\hline Vacuum delivery & Outlet Forceps delivery \\
\hline $\begin{array}{l}\text { Term pregnancy }>37 \\
\text { completed weeks }\end{array}$ & $\begin{array}{l}\text { Term pregnancy }>37 \\
\text { completed weeks }\end{array}$ \\
\hline Full dilatation & Full dilatation \\
\hline $\begin{array}{l}\text { Station+4 and more (fetal } \\
\text { head is at or on } \\
\text { perineum) }\end{array}$ & $\begin{array}{l}\text { Station+4 and more } \\
\text { (fetal head is at or on } \\
\text { perineum) }\end{array}$ \\
\hline No CPD & No CPD \\
\hline Vertex presentation & Vertex presentation \\
\hline Ruptured membranes & Ruptured membranes \\
\hline
\end{tabular}

Table 2: Exclusion criteria.

\begin{tabular}{|c|c|}
\hline Vacuum delivery & Outlet Forceps delivery \\
\hline $\begin{array}{l}\text { Malpresentation-brow, } \\
\text { face, breech }\end{array}$ & $\begin{array}{l}\text { Malpresentation- } \\
\text { brow, face, breech }\end{array}$ \\
\hline True CPD & True CPD \\
\hline Premature infants & Premature infants \\
\hline $\begin{array}{l}\text { High fetal station less } \\
\text { than }+4\end{array}$ & $\begin{array}{l}\text { High fetal station less than } \\
+4\end{array}$ \\
\hline Cervical dilation $<10 \mathrm{cms}$ & Cervical dilatation $<10 \mathrm{cms}$ \\
\hline Presence of severe caput & IUFD \\
\hline $\begin{array}{l}\text { Anomalous babies and } \\
\text { IUFD }\end{array}$ & Anomalous babies \\
\hline $\begin{array}{l}\text { Birth weight }<2.5 \mathrm{~kg} \text { and } \\
>4 \mathrm{~kg}\end{array}$ & $\begin{array}{l}\text { Birth weight }<2.5 \mathrm{~kg} \text { and }> \\
4 \mathrm{~kg}\end{array}$ \\
\hline
\end{tabular}

Maternal morbidity in terms of episiotomy extension, need for episiotomy, perinealtears, vaginal tears, hospital stay, postpartum haemorrhage, anemia,need for blood transfusion were documented.

\section{Statistical analysis}

Study design: Comparative study

Sample Size: Was estimated based on the difference in proportion of maternal morbidity (episiotomy) at term in two types of Instrumental deliveries which gave the maximum sample size for all the morbidities.

By using the formula:

$$
\text { Sample size }=r+1 / r \times\left(p^{*}\right)\left(1-p^{*} 0\right)\left(Z_{\beta}+Z_{\alpha / 2}\right)^{2} /\left(p_{1}-p_{2}\right)
$$

Where $\mathrm{r}=$ ratio of control to cases, 1 for equal number of case and control; $\mathrm{p}^{*}=$ average proportion exposed $=$ proportion of exposed cases + proportion of control $\operatorname{exposed} / 2 ; Z_{\beta}=$ Standard normal variate for power $=$ for $80 \%$ power it is 0.84 and for $90 \%$ value is 1.28 . Researcher has to select power for the study; $Z_{\alpha / 2}=$ Standard normal variate for level of significance as mentioned in previous section; $\mathrm{p}_{1}-\mathrm{p}_{2}=$ Effect size or different in proportion expected based on previous studies. $\mathrm{p}_{1}$ is proportion in cases and $\mathrm{p}_{2}$ is proportional in control.

From the Study by Singh A, Rathore P, p1 = 80\%, p2 = $93.3 \%$ at $90 \%$ confidence level $(\alpha=0.10)$ and $80 \%$ power, with equal ratio in both groups.

$\mathrm{N}=2 \times 0.866 \times 0.134(1.64+0.84)^{2}=81$ in each group

$(0.133)^{2}$

$\mathrm{P}^{*}=80+93.3 / 2=86.65$ or 0.866

Considering Non-response rate of $10 \% 81+81=90$ patients in each group was included.

Data was entered into Microsoft excel data sheet and was analyzed using SPSS 22 version software. Categorical data was represented in the form of Frequencies and 
proportions. Chi-square test was used as test of significance for qualitative data.

Graphical representation of data: MS Excel and MS word was used to obtain various types of graphs such as bar diagram. $p$ value (Probability that the result is true) of $<0.05$ was considered as statistically significant after assuming all the rules of statistical tests.

MS Excel, SPSS version 22 (IBM SPSS Statistics, Somers NY, USA) was used to analyze data. EPI Info (CDC Atlanta), Open Epi, Med calc and Medley's desktop were used to estimate sample size and reference management in the study.

In all the tables $\mathrm{n}=$ number of outlet forceps applied and vacuum applied i.e. $n=90$ for outlet forceps and vacuum.

\section{RESULTS}

Table 3: Age distribution between two groups of study.

\begin{tabular}{|lllll|}
\hline \multirow{2}{*}{ Age(years) } & \multicolumn{4}{l}{ Instrumental Vaginal Deliveries } \\
& Outlet Forceps & \multicolumn{3}{l|}{ Vacuum } \\
\hline & $\mathbf{n = 9 0}$ & $\mathbf{\%}$ & $\mathbf{n = 9 0}$ & $\mathbf{\%}$ \\
\hline$<20$ & 20 & 22.2 & 17 & 18.9 \\
\hline $21-25$ & 29 & 32.2 & 32 & 35.6 \\
\hline $26-30$ & 36 & 40.0 & 39 & 43.3 \\
\hline$>31$ & 5 & 5.6 & 2 & 2.2 \\
\hline
\end{tabular}

In the Forceps and Vacuum group majority i.e. 36 (40\%)and $39(43.3 \%)$ were in the age group 26 to 30 years respectively. There was no significant difference in age distribution between two groups.

Table 4: Parity distribution between two groups of study.

\begin{tabular}{|l|ccll|}
\hline \multirow{2}{*}{ Parity } & \multicolumn{4}{c|}{ Instrumental Vaginal Deliveries } \\
\hline & Outlet Forceps & \multicolumn{1}{l|}{ Vacuum } \\
\hline n=90 & \% & n=90 & \% \\
\hline Primigravida & 59 & 65.6 & 38 & 42.2 \\
\hline Gravida 2 & 22 & 24.4 & 46 & 51.1 \\
\hline Gravida 3 & 6 & 6.7 & 6 & 6.7 \\
\hline > Gravida 3 & 3 & 3.3 & 0 & 0.0 \\
\hline
\end{tabular}

In the Forceps group majority 59 (65.6\%) were Primigravida and in Vacuum group majority 46 (51.1\%) were Gravida 2.

There was significant difference in parity distribution between two study groups.

Most common indication in Forceps and Vacuum groups was Poor maternal bearing down efforts in 30(33.3\%) and $34(37.8 \%)$ respectively.
Next common indication for forceps was prolonged second stage in $18(20 \%)$ and in Vacuum group Severe Preeclampsia in $19(21.1 \%)$. There was no significant difference in indications between two groups.

Table 5: Comparison of Indications between outlet forceps and vacuum study groups.

\begin{tabular}{|c|c|c|c|c|}
\hline \multirow{3}{*}{ Indications } & \multicolumn{4}{|c|}{ Instrumental vaginal deliveries } \\
\hline & \multicolumn{2}{|c|}{ Outlet Forceps } & \multicolumn{2}{|c|}{ Vacuum } \\
\hline & $\mathbf{n}=90$ & $\%$ & $\mathbf{n}=90$ & $\%$ \\
\hline $\begin{array}{l}\text { Prolonged second } \\
\text { stage }\end{array}$ & 18 & 20.0 & 14 & 15.6 \\
\hline Severe pre-eclampsia & 14 & 15.6 & 19 & 21.1 \\
\hline GDM & 1 & 1.1 & 2 & 2.2 \\
\hline Fetal distress & 11 & 12.2 & 9 & 10.0 \\
\hline $\begin{array}{l}\text { Prolonged second } \\
\text { stage }+ \text { fetal } \\
\text { distress }\end{array}$ & 5 & 5.6 & 3 & 3.3 \\
\hline $\begin{array}{l}\text { Severe pre-eclampsia } \\
+ \text { fetal distress }\end{array}$ & 2 & 2.2 & 4 & 4.4 \\
\hline $\begin{array}{l}\text { Poor maternal } \\
\text { bearing down } \\
\text { efforts }\end{array}$ & 30 & 33.3 & 34 & 37.8 \\
\hline $\begin{array}{l}\text { Poor maternal } \\
\text { bearing efforts }+ \text { fetal } \\
\text { distress }\end{array}$ & 7 & 7.8 & 5 & 5.6 \\
\hline $\begin{array}{l}\text { Maternal heart } \\
\text { disease }\end{array}$ & 2 & 2.2 & 0 & 0.0 \\
\hline
\end{tabular}

Table 6: Comparison of Episiotomy extension and perineal tear between outlet forceps and vacuum study groups.

\begin{tabular}{|c|c|c|c|c|}
\hline \multirow{3}{*}{$\begin{array}{l}\text { Episiotomy } \\
\text { extension }\end{array}$} & \multicolumn{4}{|c|}{ Instrumental vaginal deliveries } \\
\hline & \multicolumn{2}{|c|}{ Outlet forceps } & \multicolumn{2}{|c|}{ Vacuum } \\
\hline & $\mathbf{N}=90$ & $\%$ & $\mathrm{~N}=90$ & $\%$ \\
\hline No extension & 71 & 78.9 & 86 & 95.6 \\
\hline $\begin{array}{l}3^{\text {rd }} \text { degree } \\
\text { perineal tear }\end{array}$ & 15 & 16.7 & 4 & 4.4 \\
\hline $\begin{array}{l}\text { Complete } \\
\text { perineal tear }\end{array}$ & 4 & 4.4 & 0 & 0.0 \\
\hline
\end{tabular}

Table 7: Comparison of Blood Transfusion between outlet forceps and vacuum study groups.

\begin{tabular}{|c|c|c|c|c|}
\hline \multirow{3}{*}{$\begin{array}{l}\text { Blood } \\
\text { Transfusion }\end{array}$} & \multicolumn{4}{|c|}{ Instrumental Vaginal Deliveries } \\
\hline & \multicolumn{2}{|c|}{ Outlet Forceps } & \multicolumn{2}{|c|}{ Vacuum } \\
\hline & $\mathrm{n}=\mathbf{9 0}$ & $\%$ & $\mathbf{n}=\mathbf{9 0}$ & $\%$ \\
\hline Required & 10 & 11.1 & 6 & 6.7 \\
\hline Not required & 80 & 88.9 & 84 & 93.3 \\
\hline
\end{tabular}

In the outlet forceps groups Episiotomy was extended up to 3rd degree in 15(16.7\%), complete Perineal tear was seen in $4(4.4 \%)$ and in Vacuum group $4(4.4 \%)$ had $3 \mathrm{rd}$ degree and $0(0 \%)$ had complete Perineal tear. 
This difference in Episiotomy extension between two groups was statistically significant.

In Forceps group $10(11.1 \%)$ required blood transfusion and in Vacuum group 6 (6.7\%)required blood transfusion. There was no significant difference in blood transfusion between two groups.

Table 8: Comparison of PPH between two study groups.

\begin{tabular}{|c|c|c|c|c|}
\hline \multirow{3}{*}{ PPH } & \multicolumn{4}{|c|}{$\begin{array}{l}\text { Instrumental Vaginal } \\
\text { Deliveries }\end{array}$} \\
\hline & \multicolumn{2}{|c|}{ Outlet Forceps } & \multicolumn{2}{|c|}{ Vacuum } \\
\hline & $n=90$ & $\%$ & $\mathrm{n}=\mathbf{9 0}$ & $\%$ \\
\hline No PPH & 78 & 86.7 & 80 & 88.9 \\
\hline Atonic PPH & 8 & 8.9 & 10 & 11.1 \\
\hline Traumatic PPH & 4 & 4.4 & 0 & 0.0 \\
\hline
\end{tabular}

In Outlet Forceps group 78(86.7\%) had no PPH, 8(8.9\%) had Atonic PPH, 4(4.4\%) had Traumatic PPH. In vacuum group 80(88.9\%) PPH was absent, 10(11.1\%) had Atonic PPH and $0 \%$ had Traumatic PPH. There was no significant association of PPH between two groups.

\section{DISCUSSION}

In the current study the use of forceps and vacuum exclusively at the outlet only was studied using 90 patients in either group.

\section{Age}

In the Present study, the mean age was 24.1 years for both groups and it was seen that $32.2 \%$ in outlet forceps group and $35.6 \%$ in vacuum group belong to age group of 21- 25 years. In a study by Gardella $C$ in 2001 mean age of use of forceps and vacuum were 26.4 years and 26.8 years respectively4. Similar type of study done by Prameela R.C in 2014 showed mean age to be 24.1 years which was similar to present study. ${ }^{5}$

\section{Parity}

In the Present study, there was high use of forceps $65.6 \%$ compared to vacuum $42.2 \%$ in primigravida. In a study by Johanson R.B, use of vacuum was $82 \%$ compared to forceps which was about $78 \%$ in primigravida. ${ }^{6}$

In a study by Gardella C, use of forceps $75 \%$ was high compared to vacuum $68 \%$ in primigravida. ${ }^{4}$

\section{Indications for application}

In present study, poor maternal bearing down efforts were the most common indication for both forceps and vacuum application. In a study by Shihadeh, failure of secondary forces was the most common indication for both forceps and vacuum extraction. ${ }^{7}$ Prameela R.C, found that forceps was used more often for prolonged 2nd stage of labor and failure of secondary forces whereas vacuum was used more frequently for fetal distress and prophylactically. ${ }^{5}$

\section{Maternal complications/morbidities}

In present study, episiotomy extension was seen in 21.1 $\%$ cases of outlet forceps and $4.4 \%$ were seen in vacuum which was statistically significant, and these results were similar to Shameel F in 2016 where $9.1 \%$ cases was applied in forceps and none in vacuum. ${ }^{8}$ Singh Abha concluded with episiotomy and extension of $40 \%$ in outlet forceps and $13.3 \%$ in vacuum group. ${ }^{9}$

In a study by Shihadeh in $1995,3^{\text {rd }}$ and $4^{\text {th }}$ perineal injuries were all significantly common in the forceps group. ${ }^{7}$ Achanna S in 1994 inferred that, incidence of birth canal trauma varied significantly with forceps being higher. ${ }^{10}$ In a study by Prameela R.C, blood transfusion was required in $10 \%$ cases of forceps and $3 \%$ in vacuum group which was almost similar to present study which required $11.1 \%$ in forceps and $6.7 \%$ in vacuum. ${ }^{5}$

In present study, there was not much significant difference between PPH in two groups but forceps group was $13.3 \%$ which was slightly higher than vacuum group. In a study by Shihadeh in 1995, PPH was more significant in forceps group i.e. $12 \%$ compared to $4 \%$ in vacuum group. ${ }^{7}$ This was almost similar to study done in 2016 by Chaudhari $\mathrm{P}$ where $7.1 \%$ cases of forceps requires blood transfusion and $1.4 \%$ of vacuum. ${ }^{11}$

\section{CONCLUSION}

In present study, maternal and neonatal outcome was assessed amongst vacuum and forceps deliveries. There was evidence of less maternal trauma with vacuum extraction than with forceps application. Fetal morbidity was higher in vacuum group compared to forceps delivery.

In today's modern obstetric era the use of operative vaginal deliveries is on a decline due to various reasons such as maternal and neonatal morbidities even though few and far in between leading to litigations.Thereby, reiterating the fact that institutional programmed training modules for younger residents in the art of operative vaginal delivery will eventually bring down the incidence of cesarean sections. With the expertise and appropriate decision on the indication and meticulous handling of the instrument whether outlet forceps or vacuum, especially in a tertiary care centre, the maternal outcome is equally good with both the instruments.

Funding: No funding sources Conflict of interest: None declared

Ethical approval: The study was approved by the Institutional Ethics Committee 


\section{REFERENCES}

1. Cunningham FG, Kenneth JL, Bloom SL, Spong CY, Dashe JS, Hoffman L et al. Williams Obstetrics. 24 ed. New York. Mc Graw Hill Education; 2010. Operative vaginal delivery: 574-85.

2. American College of Obstetricians and Gynecologists. Practice Bulletin No. 154: Operative Vaginal Deliveries. ACOG. 2011; 69-76.

3. Singh G, Gupta ED. Comparison Of Instrumental Deliveries Between Urban And Rural Hospitals:A Retrospective Study. IntJ Gynecol Obstet. 2013; 17:1-5.

4. Gardella C, Taylor M, Benedetti T, Hitti J, Critchlow C. The effect of sequential use of vacuum and forceps for assisted vaginal delivery on neonatal and maternal outcomes. Am J Obstet \& Gynaecol 2001; 185:896-902.

5. R. C. Prameela, M.B Asha, S. Prajwal. Outcome of Instrumental Vaginal Deliveries in Referred Cases. J Evol Med Dent Sci 2015;4:3275-80.

6. Johanson RB, Rice C, Doyle M, Arthur J, Anyanwu $\mathrm{L}$, Ibrahim $\mathrm{J}$ et al. A randomized prospective study comparing the new vacuum extractor policy with forceps delivery. Br J Obstet and Gynaecol. 1993; 100:524-30.
7. Shihadeh A, Al-Najdawi.Forceps or Vacuum extraction: A Comparison of maternal and neonatal morbidity. Eastern Medit Health J. 2001;71:106-14.

8. Faisal S, Bava A, Nandanwar YS. Instrumental vaginal deliveries at tertiary centre. Int J Reprod Contracept Obstet Gynecol. 2016;5:4146-50.

9. Singh A, Rathore P. A comparative study of fetomaternal outcome in instrumental vaginal delivery. $\mathbf{J}$ Obstet and Gynaecol India.2011;61:663-66.

10. Achanna S, Monga D. Outcome of Forceps delivery versus Vacuum extraction- A review of 200 cases. Singapore Med J.1994;35:605-8.

11. Chaudhari P, Bansal N, Gupta V, Tandon A, Chaudhry A. A comparative study of feto-maternal outcome in instrumental vaginal delivery at tertiary health level hospital in Uttarakhand state. Int J Reprod Contracept Obstet Gynecol.2016;5:3294-99.

Cite this article as: Singh S, Munikrishna M, Sheela SR, A comparative study of maternal outcome between vacuum extraction and outlet forceps delivery. Int J Reprod Contracept Obstet Gynecol 2018;7:2441-5. 